\title{
UPAYA PENGASUH DALAM MEMBANTU MENERAPKAN PERILAKU DISIPLIN PADA ANAK \\ (Studi Kasus di Panti Asuhan Salib Putih Salatiga)
}

\author{
Ika Wulansari' ${ }^{1)}$, Ajeng Ayu Widiastuti' ${ }^{2)}$, Tritjahjo Danny Soesilo ${ }^{3)}$ \\ 272014016@student.uksw.edu \\ ajeng.widiastuti@staff.uksw.edu \\ tritjahjo.danny@staff.uksw.edu \\ Program Studi Pendidikan Anak Usia Dini, Fakultas Keguruan Dan Ilmu Pendidikan \\ Universitas Kristen Satya Wacana
}

\begin{abstract}
This study aims to find out how caregivers in helping children to develop or build discipline from an early age conducted by 3 caregivers of the Orphanage of the White Cross on the Orphanage Children of the White Cross especially against one early childhood. The type of this research is descriptive qualitative with case study method, data collection by interview and data analysis with qualitative. In this study there are 3 subjects that help one child in building discipline. The results of the study show that the discipline of children is increasing from previously unattended discipline until now already have good discipline, in building discipline. The way in which the subject tends to be different from the other caregivers. Subjects do not use corporal punishment and it is done in a better way. The way the subject tends to be a subtle way with good advice, real stories, habits, good examples, daily schedules made, gift giving to children.
\end{abstract}

Keywords: Discipline, how to develop discipline

\section{PENDAHULUAN}

Menurut Kamus Besar Bahasa Indonesia Disiplin adalah latihan batin dan watak dengan tujuan supaya segala perhatian anak selalu mematuhi dan menaati tata tertib di sekolah maupun di rumah. Selain itu terdapat tiga arti disiplin yaitu: tata tertib, ketaatan (kepatuhan) dan bidang studi. Kedisiplinan anak adalah proses yang dilakukan oleh orang tua, pengasuh dan guru. Disiplin menurut (Sukisni, 2013) diartikan sebagai kepatuhan terhadap peraturan yang ada pada pengawasan dan pengendalian. Tujuannya adalah supaya anak mengetahui perilaku yang baik maupun yang tidak baik dan mendorong anak untuk bertindak sesuai standar yang diperlukan, yang diperlukan adalah peran orang tua, pengasuh maupun guru untuk bisa memberikan stimulasi dan campur tangan kepada anak supaya anak mengetahui perilaku yang harus dilakukan (Aulina, 2013). Disiplin adalah satu cara agar anak dapat mengembangkan pengendalian diri, dengan disiplin anak akan dapat mengetahui batasan untuk memperbaiki tingkah lakunya yang tidak benar (Anonimous, 2003; Maria, 2005 dalam (Meila, 2015). Disiplin dapat mencangkup bimbingan, pengajaran maupun dorongan yang dilakukan oleh pengasuh maupun orang tua kepada anaknya, tujuan dalam menerapkan disiplin kepada anak agar anak mau belajar menjadi makhluk sosial sekaligus agar anak mencapai perkembangan dan pertumbuhan yang optimal, Rose Mini dalam (Meila, 
2015). Hurlock dalam (Meila, 2015) mengatakan bahwa pentingnya kedisiplinan adalah guna untuk mengajarkan kepada anak hidup dalam lingkungannya dan dapat bersosialisasi dengan orang lain serta dapat memiliki moralitas yang tinggi.

Berdasarkan hasil pengamatan penulis di salah satu TK di Salatiga, penulis mendapatkan sikap anak yang masih sangat tergantung dengan pengasuh, orang tua maupun gurunya. Ketika anak melakukan beberapa kegiatan diantaranya adalah peraturan untuk menaruh sepatu pada rak sepatu, menggosok gigi sendiri, makan sendiri namun anak-anak di sekolah ini masih banyak yang bergantung kepada guru. Guru maupun orang tua akan menuruti apa yang diperintahkan anak tanpa orang tua maupun guru memberi contoh atau membiasakan anak untuk berperilaku disiplin. Dari pengamatan tersebut penulis membedakan yang terjadi di sekolah tersebut dengan yang terjadi di Panti Asuhan Salib Putih.

Panti Asuhan Salib Putih adalah salah satu panti yang ada di Salatiga. Panti Asuhan Salib Putih berada di desa sosial dimana desa sosial ini bernama desa Salib Putih. Panti Asuhan Salib Putih adalah panti asuhan yang berbeda dengan panti pada umumnya pada umumnya panti asuhan hanya beranggotakan anak-anak dengan status anak yang yatim maupun yatim piatu. Dalam Panti Asuhan Salib Putih selain anak-anak, juga beranggotakan anak remaja hingga dewasa dengan kisaran umur 5-21 tahun. Latar belakang yang dimiliki anak juga sangat berbeda. Selain itu dalam panti asuhan ini juga terdapat keberagaman agama dan suku, namun anak-anak dipanti asuhan ini bisa rukun dan dapat hidup bersama dengan baik. Dengan pengasuh yang tidak hanya fokus dengan satu anak saja namun fokus pengasuh kepada semua anak mengakibatkan pengasuh harus mampu dalam memberi pengertian kepada anak asuh dengan sikap, sifat dan karakter anak yang berbeda-beda.

Pengasuh akan mendisiplinkan mela-lui pembiasaan, mulai dari jam makan, jam mandi, jam bermain hingga jam belajar, pengasuh juga membuat jadwal keseharian anak. Berdasarkan wawancara dengan pengasuh, pengasuh menjelaskan bahwa anak-anak di panti asuhan masih mudah jika diingatkan. Pengasuh melakukan tindakan yang merangsang disiplin melalui teguran dan lain sebagainya. Ada banyak sekali cara untuk mengembangkan kedisiplinan salah satunya adalah orang tua yang menjadi model atau contoh. Lingkungan pertama yang mempengaruhi anak adalah lingkungan keluarga sendiri dan dari lingkungan keluarga tersebut anak memperoleh kemampuan dasar intelektual maupun sosial (Suryatmi, 2008).

Pada penelitian sebelumnya telah didapatkan pengembangan sikap perilaku disiplin dilakukan menggunakan metode bercerita dengan bergambar seri (Yanti, 2012). Selain itu penelitian mengenai peningkatan kedisiplinan juga dapat dikembangkan melalui pembiasaan terhadap anak (Saniopan, 2012).

Ciri khas yang dimiliki Panti Asuhan ini adalah jumlah 25 anak dengan rentan usia yang berbeda namun pengasuh memiliki cara untuk menangani anak dengan rentan usia yang berbeda sehingga penulis memilih panti asuhan sebagai tempat untuk pengambilan data, selain itu penulis melihat kedisiplinan anak TK yang sedikit lebih baik dibanding dengan anak seusianya di luar panti. Pentingnya melaku- 
kan penelitian di Panti asuhan Salib putih adalah untuk mengetahui cara yang dilakukan oleh pengasuh untuk mengembangkan kedisiplinan anak dengan cara yang berbeda dengan pengasuh pada umumnya.

Tujuan dari penelitian ini adalah untuk mengetahui cara pengasuh dalam membantu mengembangkan kedisiplinan anak di Panti Asuhan Salib Putih Salatiga.

\section{KEDISIPLINAN}

Disiplin sebagai cara agar individu maupun masyarakat mengendalikan diri dan sikap mental dalam mengembangkan ketaatan dan kepatuhan, Rachman dalam (Yanti, 2012) Prijodarminto dalam (Yanti, 2012). Perilaku itu tercipta melalui proses binaan melalui keluarga, pendidikan dan pengalaman (Hartini, 2013). Berdasarkan tanggapan diatas peneliti menyimpulkan bahwa adanya kedisiplinan karena adanya perilaku yang mencerminkan nilai ketaatan, kepatauhan, keteraturan dan atau ketertiban, baik tertulis maupun tidak tertulis. Disiplin pada anak usia pra sekolah sangat perlu ditanamkan dalam menata tingkah lakunya karena anak nantinya akan menghadapi segala pengaruh-pengaruh dari lingkungan luar (Martha Efirlin, 2014).

Disiplin sebagai cara anak dalam mengembangkan perilaku sesuai dengan aturan yang sudah ditetapkan oleh masyarakat dengan 5 unsur yaitu peraturan, kebiasaan-kebiasaan, hukuman, penghargaan dan menciptakan lingkungan yang kondusif (Yanti, 2012).

Aspek yang membangun kedisiplinan menurut Depag. RI 2006, dalam (Hartini, 2013) yaitu kontrol dari orang tua, tuntutan kedewasaan, kejelasan komunikasi dan asuhan orang tua.
Faktor-faktor yang mempengaruhi kedisiplinan antara lain lingkungan sekolah, keluarga, tingkat sosial ekonomi, tingkat pendidikan dan kepribadian Djulaeha dalam (Hartini, 2013)

Manfaat kedisiplinan menurut (Desti, 2014) menumbuhkan kepekaan, kepedulian, ketenangan, sikap percaya diri, kemandirian, kapatuhan, keakraban, mengajarkan keteraturan, membantu perkembangan otak, membantu anak yang "sulit".

\section{PERAN PENGASUH}

Panti asuhan adalah tempat untuk mengasuh anak yang yatim maupun yatim piatu, dan juga anak-anak terlantar untuk dibina dan dibimbing agar menjadi anak yang mandiri, bertanggung jawab, patuh dan taat serta dapat berguna bagi masyarakat sekitar nusa dan bangsa (Suryatmi, 2008). Menurut Departeman sosial Paulina dalam (Suryatmi, 2008) mengatakan bahwa fungsi dari panti asuhan sendiri adalah untuk menampung dan membimbing anak-anak yatim, yatim piatu maupun keduanya, anak-anak terlantar bahakan anak-anak yang kesulitan dalam ekonomi untuk memperoleh perhatian berupa pemenuhan kebutuhan dan juga dapat memperoleh status sosial yang layak. Panti asuhan adalah tempat yang dikelola dengan asas kekluargaan bagi anak asuh, dengan susasan kekeluargaan dalam kehidupan sehari-hari dengan tujauan anak dapat merasakan berada dalam keluarga sendiri sekalipun pada kenyataannya mereka telah berpisah dengan keluarga mereka.

Peran pengasuh adalah cara pengasuh dalam hal ini memberikan segala sesuatu yang dibutuhkan baik perhatian, waktu dan juga dukungan agar dapat memenuhi 
kebutuhan fisik, mental dan juga sosial anak-anak yang sedang dalam masa perhatian, Kozier Barbara dalam (syahrony, 2013). Penguatan fungsi orang tua atau pengasuh sebagai penanggung jawab utama dalam pengasuhan anak perlu segera dilakukan. Menurut Naswardi dalam (Budiharjo, 2015) program penguatan dan pengembangan ketahanan keluarga dimaksudkan untuk meningkatkan kemampuan keluarga supaya keluarga memiliki ketangguhan dan keuletan, menjadi sumberdaya manusia yang tangguh, mandiri, bermoral dan juga berkualitas.

Untuk dapat berkembang secara utuh dalam kehidupannya seorang anak memerlukan model atau contoh. Model atau contoh yang dekat dari anak adalah lingkungan keluarga, dari anggota keluarga tersebut seorang anak dapat memperolah kemampuan dasar baik kemampuan intelektual maupun kemampuan sosial. Bahkan penyaluran emosi banyak ditiru dari anggota lain didalam keluarga. Pribadi yang mudah dan dekat untuk dijadikan model atau contoh seorang anak adalah orang tua, oleh sebab itu kehadiran dan interaksi yang baik antara orang tua dan anak akan berpengaruh dalam perkembangan pribadi seorang anak, (Suryatmi, 2008).

Berdasarkan kebutuhan anak akan figur orang tua maka Panti Asuhan sebagai lembaga yang memberikan bimbingan, pemeliharaan, perawatan dan pendidikan pada anak diharapkan dapat menjadi keluarga yang menghadirkan figur orang tua bagi anak asuhnya. Sekalipun seorang anak asuh tinggal di Panti Asuhan namun kebutuhan akan figur orang tua tetap dapat terpenuhi, (Suryatmi, 2008). Begitu pula dengan sikap pengasuh yang menempatkan mereka sebagai orang tua.

Menurut (Suryatmi, 2008) mengatakan Pengasuh di Panti Asuhan adalah orang yang mendedikasikan dirinya untuk tinggal bersama-sama dengan anak-anak asuh yang berperan sebagai orang tua anak asuh. Pengasuh sebagai orang tua di Panti Asuhan bertugas untuk memelihara dan mendidik penghuni panti dengan berbagai kegiatan. Setiap kegiatan yang dilakukan anak asuh pengasuh harus bertanggung jawab dengan tugasnya, tugas pengasuh diaplikasikan dalam bentuk tindakan dan kegiatan sehari-hari bersama anak-anak asuh, beberapa kegiatan yang dilakukan oleh pengasuh adalah sebagai berikut :

a. Asuh

1). Makan minum

Setiap anak yang tinggal dipanti asuhan adalah anak-anak yang berada dalam proses pertumbuhan secara fisik. Oleh sebab itu anak-anak asuh membutuhkan asupan gizi melalui makanan mereka. Aturan makan tiga kali sehari yaitu pagi, siang dan malam merupakan aturan yang sudah ditetapkan untuk membantu penghuni panti asuhan untuk dapat bertumbuh dengan baik.

2). Tempat tinggal

Selain makanan bergizi anak-anak juga membutuhkan tempat tinggal dimana anak-anak panti dapat bertumbuh secara optimal, tempat tinggal yang baik adalah tempat tinggal yang nyaman untuk anak.

3). Perawatan kesehatan

Selain makanan bergizi dan tempat tinggal yang nyaman, anak- 
anak juga membutuhkan perawatan kesehatan guna mencegah timbulnya gangguan kesehatan. Tempat tinggal dan lingkungan yang baik dan bersih merupakan salah satu cara bagi perawatan kesehatan diri.

b. Asah

1) Kegiatan belajar

Kegiatan belajar bertujuan untuk mengembangakan kemampuan dasar belajar anak, kemampuan ini dikembangkan dengan cara menanamkan kebiasaan belajar yang baik bagi penghuni panti. Melalui kegiatan belajar ini diharapakan penghuni panti dapat megembangkan bakat, kemandirian serta tanggung jawab pada diri sendiri serta komunitas dimana mereka tinggal yaitu di Panti Asuhan.

2) Kegiatan pengembangan potensi (bakat)

Kegiatan ini mencangkup penyaluran hobi dan kemampuan-kemampuan diluar kemampuan akademik. Kemampuan yang disalurkan terutama kemampuan seni, dan kepemimpinan. Kegiatan ini melatih anak untuk mengembangkan potensi yang dimiliki dan yang belum tersalurkan.

c. Asih

1) Bimbingan rohani

Setiap penghuni panti asuhan diberikan bimbingan rohani. Kegiatan ini bertujuan untuk membangun sikap, perilaku dan kebiasaan untuk dekat dengan Tuhan. Baik kegiatan pribadi maupun kegiatan bersama-sama.

2) Bimbingan emosional

Dalam hal ini penghuni panti dibantu dalam mengenali emosi yang terjadi dalam diri mereka dan mengelola emosi secara tepat dan mengungkapkan secara tepat supaya menghasilkan perilaku yang benar.

\section{METODE PENELITIAN}

Model dalam penelitian adalah penelitian kualitatif. Alsa (dalam (Herma, 2013) mengatakan bahwa penelitian kulaitatif bertujuan untuk memeahami objeknya, tidak untuk menemukan hukumhukum yang dilandasi sebab akibat. Salah satu ciri yang khas dalam penelitian kualitatif yaitu memiliki sifat lebih alami, holistik, memiliki unsur budaya dan didekati secara kasuistik, Idrus dalam (Herma, 2013). Dengan demikian diharapkan dapat memahami metode refleksi untuk mengembangkan kedisiplinan anak di Panti Asuhan salib Putih Salatiga.

Metode penelitian yang dilakukan berupa deskriptif kualitatif. Menurut (Sugiyono, 2010) bahwa penelitian kualitatif deskriptif adalah metode penelitian yang berdasarkan pada filsafat postpositivisme yang biasanya digunakan untuk meneliti pada kondisi objektif yang alamiah dimana yang berperan sebagai insstrumen kunci adalah peneliti.

Jenis penelitian ini berupa studi kasus sebagai proses untuk mengetahui cara yang dilakukan oleh pengasuh untuk 
mengembangkan kedisiplinan anak secara mendalam, peneliti menyelidiki secaracermat suatu program, peristiwa, aktivitas, proses atau sekelompok individu, kasus-kasus dibatasi oleh waktu dan aktivitas, dan juga peneliti mengumpulkan informasi secara lengkap dengan menggunakan beberapa prosedur dalam pengumpulan data dengan berdasarkan waktu yang telah ditentukan, Stake dalam (Creswell, 2009).

Penulis memilih studi kasus agar memahami dan menjelaskan lebih dalam subjek yang akan diteliti. Selain itu, juga bertujuan untuk mengungkapkan kekhasan dan keunikan karakteristik yang terdapat di dalam kasus. Metode pengumpulan data dari penelitian ini adalah observasi dan dokumentasi.

Analisis dalam penelitian kualitatif adalah dengan mencari dan menyusun secara sistematis, data yang diperoleh adalah dari hasil wawancara, observasi dan juga dokumentasi dengan cara mengkoordinasikan data kedalam kategori, dan juga dapat dijabarkan kedalam unitunit, juga melakukan sintesa, menyusun kedalam pola, kemudian memilih mana yang penting dan yang akan dipelajari kemudian membuat kesimpulan sehingga mudah dipelajari oleh diri sendiri maupun oleh orang lain, Sugiyono dalam (Herma, 2013).

\section{HASIL DAN PEMBAHASAN}

Penelitian ini dilakukan di Panti Asuhan Salib Putih Jl. Hasanudin KM. 04 Salatiga. Wawancara dilakukan kepada 3 pengasuh dan 1 informan tambahan. Narasumber yang berhasil diwawancarai secara intensif dengan nama inisial ER, VI, YK dan narasumber informan IN.

\section{TEMUAN UMUM}

Dalam temuan umum ini berisi tentang kesamaan dari subjek dalam membangun kedisiplinan anak, diantaranya adalah : Pembiasaan

Pembisaan yang dilakukan oleh ketiga subjek dilakukan untuk membangun kedisiplinan anak. pembiasaan yang dilakukan oleh subjek adalah pembiasaan seperti membiasakan anak untuk bangun pagi, doa pagi, mandi sore, belajar dll. Pembiasaan yang dilakukan oleh pengasuh adalah dengan jadwal rutin harian (ER, 30 November 2017). Selain dengan jadwal rutin juga dengan pengasuh memberikan contoh kepada anak (VI, 30 November 2017).

\section{Mengajari dari Hal Kecil}

Mengajari hal dari hal kecil ini tidak jauh dari pembiasaan dimana dalam hal ini pengasuh mengajari anak dari hal-hal kecil seperti membuang sampah pada tempatnya, hal ini dilakukan pengasuh. ER dan VI melakukan hal dengan mengajarkan dari hal kecil sejak anak masuk pertama di panti asuhan seperti bangun pagi, berangkat sekolah tepat waktu dll (30 November 2017).

\section{Memberi Nasehat dan Menghindari Hukuman Fisik}

Ketiga pengasuh mengatakan bahwa kedisiplinan tisak selamanya dilakukan dengan hukuman fisik atau kekerasan fisik, para pengasuh beranggapan selama anak masih bisa dinasihati mengapa harus diberi hukuman fisik. Anak dapat dinasehati ketika ada komunikasi yang rutin dengan pengasuh, dalam hal ini pengasuh berusaha menghindari hukuman fisik namun 
pengasuh berusaha untuk memberikan reward kepada anak (ER, 3 Oktober 2017). Untuk menghindari hukuman fisik juga dapat melakukan peringatan terus menerus terhadap anak (VI, 30 November 2017). Untuk menghidari hukuman kekerasan fisik dapat dilakukan dengan cara menyita barang milik anak namun hal ini tidak bertahan lama karena ketika anak sudah melakukan hal baik anak akan mendapatkan barangnya kembali (YK, 30 November 2017).

\section{Memberikan Pujian atau Hadiah}

Hadiah atau pujian dapat dilakukan pengasuh ketika anak disiplin atau tidak membangkang. Namun anak tidak akan mendapatkan sesuatu ketika anak tidak disiplin, akan tetapi pemberian hadiah ini pengasuh akan memberi pengertian bahwa reward tidak selamanya barang namun bisa berupa pujian (ER, 3 Oktober 2017).

\section{TEMUAN KHUSUS}

Selain ada perbedaan yang dilakukan oleh pengasuh yang telah dipaparkan ditemuan umum, temuan khusus menyingung tentang perbedaan pendapat ataupun cara yang dilakukan oleh pengasuh diantaranya adalah :

\section{Pengertian Kedisiplinan}

ER mengatakan bahwa kedisiplinan adalah bertanggung jawab secara sadar dimana anak bertanggung jawab tanpa adanya paksaan(30 Oktober 2017). VI memiliki pendapat yang berbeda dimana VI menjelaskan bahwa kedisiplinan merupakan mengikuti aturan yang sudah dibuat(30 Oktober 2017). YK juga memiliki pendapat yang berbeda YK mengatakan bahwa arti kedisiplinan adalah ketika anak nurut (28 November 2017).

\section{Pentingnya Kedisiplinan}

ER mengatakan bahwa pentingnya kedisiplinan adalah agar anak tidak seenaknya sendiri dan tidak melanggar tata tertib (30 Oktober 2017). Sedangkan pentingnya kedisiplinan yang diungkapkan oleh VI adalah bekal untuk kehidupan kelak ketika anak sudah hidup bermasyarakat (30 Oktober 2017). Yk berpendapat bahwa pentingnya kedisiplinan adalah bekal untuk anak ketika anak sudah bertambah level kelasnya dan bekal untuk anak ketika anak sudah semakin besar (28 Oktober 2017).

\section{Tahapan Kedisiplinan}

Tahapan kedisiplinan menurut ER adalah yang pertama anak benar-benar mengerti tentang kedisiplinan dan yang kedua adalah apa tingkat kedisipllinan yang dimiliki anak dan bagaimana anak bisa melakukan kedisiplinan itu sendiri (30 November 2017). Tahapan kedisiplinana yang diungkapkan VI adalah tahapan kedisiplinan yang digolongkan sesuai usai anak, dimana setiap anak dengan usia yang berbeda-beda akan memiliki tahapan kedisiplinan yang berbeda pula (30 Oktober 2017). YK juga mengatakan bahwa tahapan kedisiplinan adalah dilihat sesuai usia anak (28 Oktober 2017).

\section{Cara Menerapkan Kedisiplinan}

Cara menerpkan kedisiplinan yang dilakukanoleh ER adalah melakukan semua hal yang diajarkan secara konsisiten (30 November 2017).

Selain adanya pembahasan dari temuan umum dan khusus yang ditemukan dari 
ketiga subjek, penulis juga menemukan temuan yang berasal dari informan tambahan dengan inisial IN. IN mengatakaan bahwa pengasuh benar-benar mengajarkan kedisiplinan selain melihat In adalah salah satu anak didikan dari ketiga subjek dimana IN juga merasakan didikan tersebut (30 November 2017).

\section{OBSERVASI HARIAN}

\begin{tabular}{|c|c|}
\hline Tanggal Observasi & Hasil observasi \\
\hline 2 November 2017 & $\begin{array}{l}\text { ER : memberikan contoh siap jam setengah } 8 \text { ketika akan berangkat } \\
\text { sekolah } \\
\text { VI : memberikan donat karena sudah mandi tepat waktu } \\
\text { YK : - }\end{array}$ \\
\hline 6 November 2017 & $\begin{array}{l}\text { ER : memberi peringatan ketika anak masih bermain kelereng } \\
\text { padahal jadwal anak seharusnya mandi karena anak terlalu asik ER } \\
\text { menyita barang yang disukai sampai anak memperbaiki kesalahan } \\
\text { VI : mengkomunikasikan dengan YK tentang anak yang susah makan } \\
\text { siang dengan banyak alasan } \\
\text { YK : marah-marah karena anak tidak makan siang }\end{array}$ \\
\hline 8 November 2017 & $\begin{array}{l}\text { ER : memberi peringatan karena anak telat mandi sore } \\
\text { VI : memberi nasihat karena anak terlalu asik bermain dan menjadi } \\
\text { telat mandi sore } \\
\text { YK : - }\end{array}$ \\
\hline 11 November 2017 & $\begin{array}{l}\text { ER :- } \\
\text { VI : memberi nasihat ketika anak tidak tidur siang } \\
\text { YK : memberikan contoh tidur siang }\end{array}$ \\
\hline 14 November 2017 & $\begin{array}{l}\text { ER : bersama dengan VI dan YK mengkomunikasikan kegiatan anak } \\
\text { VI : - } \\
\text { YK : memberikan uang jajan } 2 \mathrm{rb} \text { karena anak mau tidur siang dan } \\
\text { mengingatkan YK untuk menemani anak tidur siang }\end{array}$ \\
\hline 15 November 2017 & $\begin{array}{l}\text { ER : ER dan VI mengajak jalan jalan anak dan juga teman-temannya } \\
\text { ketaman kota karena anak sudah mau berbagi dan saling } \\
\text { mengingatkan jadwal kegiatan hari itu } \\
\text { VI : } \\
\text { YK :- }\end{array}$ \\
\hline $\begin{array}{c}20 \text { dan } 21 \\
\text { November } 2017\end{array}$ & Karena anak sakit anak tidak melakukan jadwal harian dengan tepat \\
\hline $\begin{array}{c}3,7,9,10,13,14 \\
16,17,21,22,23 \\
24,25,27,28,30 \\
\text { November } 2017\end{array}$ & $\begin{array}{l}\text { Anak melakukan kegiatan rutin sesuai dengan jadwal harian. } \\
\text { Pengasuh tetap berusaha melakukan pembiasaan, memberikan contoh } \\
\text { meskipun anak sudag melakukan dengan baik. }\end{array}$ \\
\hline
\end{tabular}




\section{PEMBAHASAN}

Dalam mengembangkan kedisiplinan terhadap anak usia dini di Panti asuhan salib Putih, peneliti menemukan temuan umum dan temuan khusus. Temuan umum adalah temuan dimana ketiga subjek memiliki cara yang sama dalam mengembangkan kedisipinan anak, namun pengasuh juga memiliki cara dan pemahaman yang berbeda dimana temuan yang berbeda tersebut dipaparkan pada temuan khusus. Disiplin sering kali diajarkan oleh orang tua maupun pengasuh sejak dini, begitu pula yang dilakukan oleh pengasuh di Panti Asuhan Salib Putih dimana telah mengajarkan kedisiplinan sejak dini. Kedisiplinan yang diharapkan ketika anak berada di Panti Asuhan adalah untuk bekal ketika anak sudah hidup bermasyarakat. Pentingnya kedisiplinan bagi anak maka setiap orang perlu sekali menanamkan kedisiplinan sejak dini hal tersebut akan membantu anak untuk dapat menyesuaikan diri dengan aturan lingkungan baru yang akan dimasuki (Wahyu, 2015). Pengasuh sangat berperan dalam mengembangkan kedisiplinana anak, pengasuh menempatkan diri bahwa seolaholah mereka adalah orang tua.

(Budiharjo, 2015) yang menjelaskan bahwa banyak pengasuh yang masih memiliki paradigma diujung rotan terdapat emas, sehingga tidak jarang pemberian sanksi dan punishment terhadap anak yang dianggap melanggar aturan-aturan internal dilakukan melalui penghukuman yang syarat dengan kekerasan baik sisik, verbal dan psikologi. Berbeda dengan pendapat Budiharjo diatas pengasuh Panti Asuhan Salib Putih sangat menghindari kekerasan seperti yang dikatan oleh Budiharjo.
Menasihati, konsisten, tidak memberi hukuman fisik, membuat konsekuensi, memberi peringatan dan pembiasaan, adalah beberapa cara yang dilakukan pengasuh untuk menerapkan perilaku disiplin anak di Panti asuhan salib Putih. (Shochib, 2010) mengatakan pada masa kanak-kanak (1-7 tahun) disarankan menggunakan pemberian contoh (teladan) dan pembiasaan dalam perkembangan anak salah satunya adalah perkembangan sikap perilaku disiplin.

Erviana dalam (Saniopan, 2012) mengatakan bahwa pembiasaan pada usia pra sekolah salah satu pendidikan yang penting sekali bagi kecakapan seseorang (anak), sebab pada usia pra sekolah, anak belum menyadari apa yang dikatakan dan dilakukannya, baik maupun buruk. Begitu pula dengan pengasuh yang setiap hari melakukan pembiasaan terhadap anak karena para pengasuh sadar bahwa anak mempunyai hak dipelihara, hak mendapatkan perlindungan dan hak mendapatkan pendidikan.

Budiharjo (2015) mengatakan bahwa ketika anak bisa mencontoh hal kecil dari kita maka itu adalah salah satu bibit dimana anak menjadi seorang baik dikemudian hari, jika kelak anak akan menjadi pemimpin maka tata nilai yang sudah ditanamkan akan digunakan oleh anak. Begitu juga dengan pengasuh yang selalu memberikan contoh untuk anak asuh agar anak bisa melakukan dengan baik dan sebagai bekal ketika anak hidup dalam masyarakat.

Cerita atau contoh yang diberikan pengasuh kepada anak juga menggunakan cerita nyata, tidak dibuat-buat dan disesuaikan dengan kesalahan anak. setelah anak mendengar atau diberitahu melalui 
nasihat tersebut anak akan dipersilahkan oleh pengasuh untuk memperbaikinya secara langsung. Pengasuh di Panti Asuhan Salib Putih ini juga berbeda dengan Panti Asuhan lain. Pengasuh dari Panti Asuhan lain lebih memilih mendisiplinkan anak melalui hukuman seperti menyapu, membersihkan kamar mandi dll.

Cara yang dilakukan oleh ketiga pengasuh dapat membuat anak-anak belajar menerapkan sikap perilaku disiplin khususnya anak-anak Panti Asuhan Salib Putih. Pengasuh melakukan dengan terus saling berkomunikasi secara rutin supaya tidak ada kesalahpahaman antar pengasuh. Dari cara yang dilakukan oleh pengasuh telah dibuktikan dari anak-anak Panti Asuhan yang sudah disiplin, karena telah ditanamkan sikap disiplin sejak dini.
Namun pengasuh di Panti Asuhan Salib Putih berbeda, pengasuh di sini sangat menghindari sekali yang namanya hukuman fisik, karena menurut merka hukuman fisik tidak akan menyelesaikan masalah namun akan menambah masalah. Pengasuh mengatakan bahwa menggunakan cerita atau nasihat yang lebih nyata maka anak akan mengetahui dan menyadari bahwa hal yang mereka lakukan akan ada akibatnya.

Pengasuh di tempat ini juga selalu mengusahakan ketika anak melakukan hal yang baik atau disiplin maka anak akan mendapatkan hadiah berupa barang maupun pujian. Pada intinya pengasuh membangun kedisiplinan anak asuh di Panti Asuhan Salib Putih melalui nasihat yang nyata, pembiasaan melalui jadwal harian dan juga selalu memberi pujian bagi anak dan selalu menghindari hukuman fisik.

\section{KERANGKA KEDISIPLINAN}

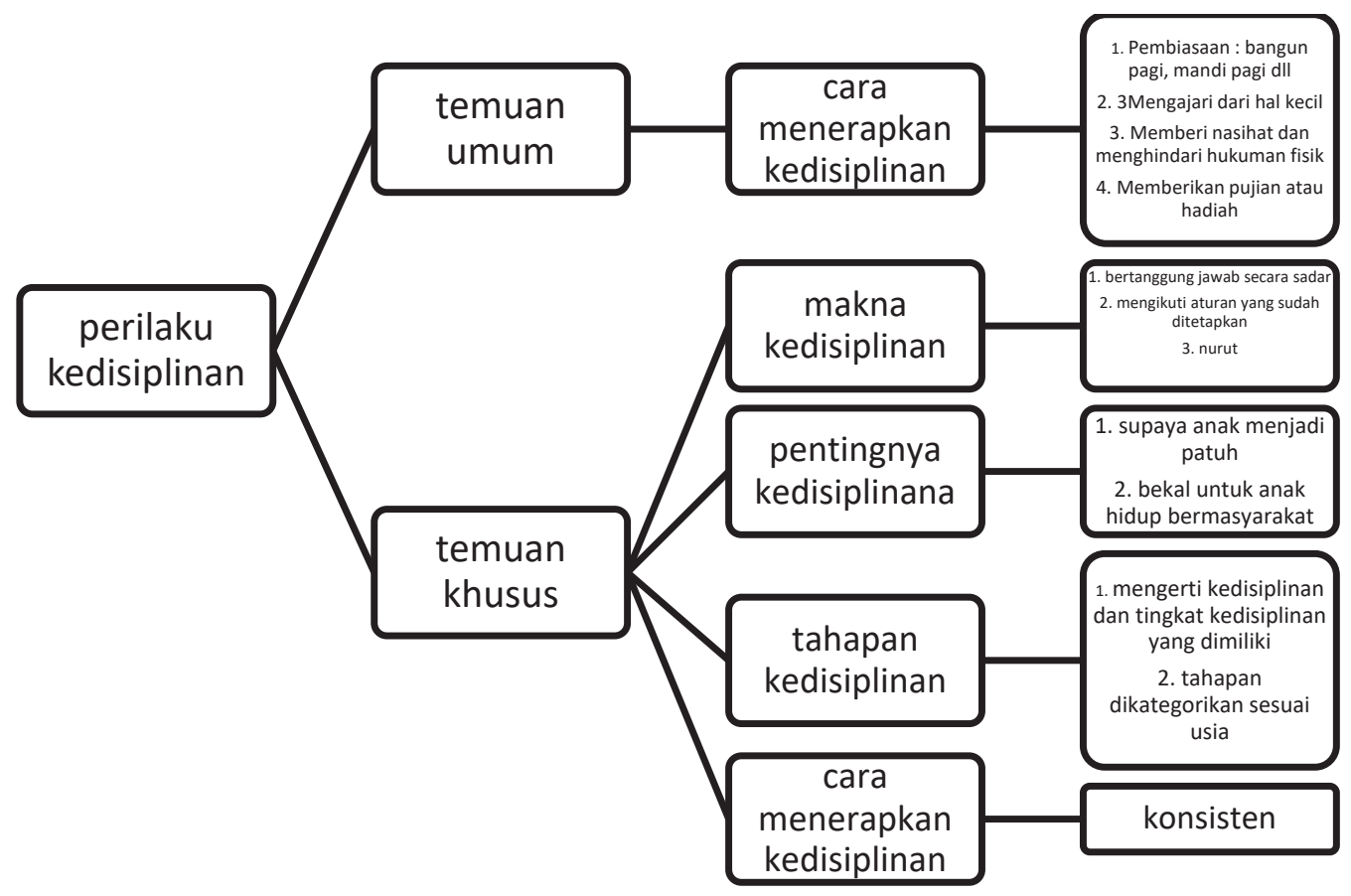




\section{KESIMPULAN DAN SARAN}

Berdasarkan hasil penelitian yang sudah dilakukan oleh penulis didapatkan cara yang dilakukan oleh pengasuh dan digolongkan kedalam temuan umum dan temuan khusus. temuan umum adalah temuan yang sama dalam subjek melakukan untuk mengembangkan kedisiplinan terhadap anak seperti: pembiasaan, mengajari dari hal kecil, menghindari hukuman fisik dan memberi nasehat, memberikan pujian atau hadiah. Selanjutnya adalah temuan khusus dimana subjek memiliki cara atau pemahaman yang berbeda dalam mengembangkan kedisiplinan anak yaitu pemahaman dari makna kedisiplinan, pentingnya kedidiplinan dan juga tahapan kedidiplinan dan juga satu cara yang berbeda adalah dengan perilaku yang konsisten.

Dalam penelitian ii juga didapat bahwa untuk mendisiplinkan anak dapat dilakukan dengan memberikan sebuah nasehat, pembiasaan dan juga tanpa kekerasan fisik. Adapun saran-saran peneliti yang diharapkan berguna bagi kedisiplinan anak adalah: Ada baiknya sebagai pengasuh tidak mendisiplinkan anak asuh dengan hukuman fisik. Dapat dilakukan melalui nasehat yang nyata maupun membiasakan anak melalui jadwal harian. Peneliti atau penulis selanjutnya diharapkan memaksimalkan teknik pengumpulan data, seperti wawancara, observasi, dokumentasi agar lebih dapat bervariasi sehingga diperoleh data yang akurat dan tepat bagi keberhasilan penelitian lebih lanjut mengenai halhal yang berkaitan dengan kedisiplinan anak usia dini.

\section{DAFTAR PUSTAKA}

Aulina, C. N. (2013). Penanaman Disiplin Pada Anak Usia Dini. Universitas Muhammadiyah Sidoarjo , 2.

Budiharjo. (2015). Pendidikan Pengasuh Pada Panti Sosial Asuhan Anak Milik Organisasi Masyarakat Islam Di DKI Jakarta. Fisip Universitas Prof. Dr. Moestopo Senayan Jakarta.

Creswell, J. (2009). Research Design Pendekatan Kualitatif, Kuantitatif Dan Mixed. Yogyakarta: Pustaka Pelajar.

Desti, H. (2014). Meningkatkan Kedisiplinan Melalui Metode Bercerita Pada Kelompok Bermain Di PAUD Amanah Kota Lubuklinggau. Universitas Bengkulu.

Hartini. (2013). Pengembangan

Kedisiplinan Melalui Metode Bermain

Peran Makro Pada Taman Kanak-

Kanak Pertiwi Wanglu Kelompok A

Kecamatan Trucuk Kabupaten Klaten

Tahun Pelajaran 2012-2013.

Universitas Muhammadiyah

Surakarta.

Herma, N. M. (2013). Kondisi Psikologi

Pada BIseksual (studi kasus pada mahasiswa biseksual di Yogyakarta).

Universitas Islam Negeri Sunan

Kalijaga Yogyakarta.

Martha Efirlin, F. M. (2014). Penanaman

Perilaku Disiplin Anak Usia 5-6

Tahun Di TK Primanda UNTAN Pontianak. Fakultas Keguruan Dan Ilmu Pendidikan UNTAN , 2.

Meila, A. (2015). Hubungan Reward Dengan Disiplin Anak TK Kelompok B Di Sekolah Se-gugus II Kecamatan Sanden, Bantul. Universitas Negeri Yogyakarta, 2. 
Saniopan, A. (2012). Meningkatkan kedisiplinan Anak Melalui

Pembiasaan Di Kelompok B PAUD Negeri Pembina Palu. Universitas Tadulako, 668 .

Shochib, M. (2010). Pola asuh Orang Tua Dalam Membantu Anak Mengembangkan Disiplin Diri. Jakarta: Rineka Cipta.

Sugiyono. (2010). Metode Penelitian Pendidikan Pendekatan Kualitatif, Kuantitatif Dan $R \& D$. Bandung: Alfabeta, $\mathrm{Cv}$.

Sukisni, N. (2013). Peningkatan Kedisiplinan Anak Melalui Metode Bercerita dengan Wayang Kardus pada Anak kelompok B Di Taman Kanak-kanak Kasih Bunda 02 Karangpelem, Kedawung, Sragen Tahun Pelajaran 2012/2013. Universitas Muhammadiyah Surakarta .
Suryatmi, M. (2008). Hubungan Peran Pengasuh Dan Keterpenuhan Kebutuhan Pada Aspek-Aspek Perkembangan Pribadi Yang Integral Anak-Anak Asuh Di Panti Asuhan El Jireh Yogyakarta. Universitas Sanata Dharma Yogyakarta.

syahrony, w. r. (2013). Peran Pengasuh Di Panti Asuhan Al-Amien Pontianak. Universitas Tanjungpura.

Wahyu, Z. A. (2015). Menanamkan Nilai Disiplin Anak Pada Lingkungan Keluarga Di Desa Sungai Pinang Lama Kecamatan Sungai Tabuk Kabupaten Banjar. Universitas Lambung Mangkurat , 5, 853.

Yanti, T. Y. (2012). Meningkatkan Disiplin Anak Melalui Metode Bercerita Pada KelompokA Di TK Islam Mutiara Surabaya. Universitas Negeri Surabaya, 2. 